\title{
THE COMPARATIVE ANALYSIS OF APPROACHES TO EVALUATION OF VALUE-BASED ORIENTATIONS FOR SOCIOLOGICAL INVESTIGATIONS IN THE FIELD OF CORRUPTION
}

\author{
${ }^{1}$ A.A. Satybaldyn, ${ }^{2}$ T.M. Rezer, ${ }^{3}$ A.Zh. Panzabekova
}

\begin{abstract}
The topicality of the research is stipulated by the growing necessity to investigate the degree of corruption perception in societies capable to reveal the motives, cultural and socialpsychological tendencies to corruption offences to develop a set of measures aimed at eliminating social and cultural reasons of the corruption. The current paper suggests applying methods of personal and societal value-based orientations estimation as such investigations. The paper is aimed at analysis comparing four most known and successful techniques on value-based orientations estimation (Schwartz value survey, Rokeach value survey, the Diagnostics of person value orientations structure by S.Bubnova, and the World assumptions scale by R. Janoff-Bulman adapted by O.Kravtsova) in the context of its applicability to determine the degree of the corruption perception. The paper shows advantages and disadvantages of the analyzed methods for the corruption perception researches. It was determined that for the use in corruption perception researches, some of the considered methods require the inclusion of additional issues on corruption component. The authors propose the formulation of such issues by Schwartz survey and adapted Janoff-Bulman scale. The results of the research represent the evaluation of each of the considered techniques from 1 to 4 points scale by the following criteria: survey scale, complexity of survey, complexity of analysis and interpretation of results, complexity of corruption perception issues integration
\end{abstract}

Keywords: Values, Value-Based Orientations, Perception of Corruption, Methods of Value Orientations Evaluation

\author{
1-3 Institute of Economics, CS \\ MES RK, Almaty, Kazakhstan \\ ${ }^{2}$ Yeltsin Ural Federal \\ University, Yekaterinburg, \\ Russia \\ Corresponding Author: \\ А.Ж. Панзабекова, \\ aksanat@mail.ru \\ Reference to this article: \\ Panzabekova A.Zh.The \\ comparative analysis of \\ approaches to evaluation of \\ value-based orientations for \\ sociological investigations \\ in the field of corruption // \\ Adam alemi. - 2021. \\ - №3 (89). - Б. 92-99.
}

The article was prepared within the framework of grant funding for scientific projects of the Ministry of Education and Science of the Republic of Kazakhstan (IRN: AP08856570 "Socio-cultural factors of corruption and the concept of forming an anti-corruption culture in Kazakhstani society"). 


\title{
Сравнительный анализ подходов к оценке ценностных ориентаций для проведения социалогических исследований в сфере коррупции
}

\begin{abstract}
Аннотация. Актуальность исследования обусловлена растущей потребностью в исследованиях уровня восприятия коррупции в обществах, способных выявить мотивы, культурные и социально-психологические склонности к коррупционным правонарушениям для разработки комплекса мер, направленных на искоренение социокультурных причин коррупции. В настоящей статье в качестве подобных исследований предлагается использовать методы оценки ценностных ориентаций личности и общества. Целью статьи является проведение сопоставительного анализа четырех наиболее известных и успешных методик оценки ценностных ориентаций (методика ценностных ориентаций Ш.Шварца, «Ценностные ориентации» М. Рокича, диагностика структуры ценностных ориентаций личности С. Бубновой и Тест базовых убеждений Р. Янов-Бульман в адаптации О. Кравцовой) в контексте их применимости в определении уровня восприятия коррупции. В статье даны преимущества и недостатки использования анализируемых методик в исследовании воспрития коррупции. Установлено, что для использования в исследованиях восприятия коррупции, некоторые из рассматриваемых методик требуют интегрирования в них дополнительных вопросов по коррупционной составлящей. Авторами предложена формулировка подобных вопросов по опроснику Ш.Шварца и адаптированному опроснику Р.Янов-Булмана. Результаты исследования представляют собой оценку каждой из рассмотренных методик по шкале от 1-го до 4-х по следующим критериям: масштаб опроса, сложность проведения, сложность анализа и интерпретации результатов, сложность интеграции вопросов о восприятии коррупции.
\end{abstract}

Ключевые слова: ценности, ценностные ориентации, восприятие коррупции, методики оценки ценностных ориентаций.

\section{Сыбайлас жемқорлықты қабылдауды зерттеуде қолдануға болатын құндылық бағдарларды бағалау тәсілдерін салыстырмалы талдау}

Аңдатпа. Зерттеудің өзектілігі сыбайлас жемқорлықтың әлеуметтік-мәдени себептерін жою мақсатында шаралар әзірлеу үшін сыбайлас жемқорлық құқық бұзушылық себептерін, мәдени және әлеуметтік-психологиялық бейімділігін анықтауға қабілетті қоғамдағы сыбайлас жемқорлықты қабылдау деңгейін зерттеуге қажеттіліктің артуымен байланысты. Бұл мақалада осындай зерттеулер ретінде жеке адам мен қоғамның құндылық бағдарын бағалау әдістерін қолдану ұсынылады. Мақаланың мақсаты - құндылық бағдарын бағалаудың ең танымал және табысты төрт әдісіне (Ш.Шварцтың құндылық бағдарлау әдісі, М. Рокичтің «Құндылық бағдарлары», құндылық бағдарларының құрылымының диагностикасы, С. Бубнова бойынша жеке тұлғаның құндылық бағдарларының нақты құрылымының диагностикасы және О. Кравцованың бейімделуіндегі Р. Янов-Булманның негізгі сенімдерін тесті) сыбайлас жемқорлықты қабылдау деңгейін анықтауда қолданылуы тұрғысынан салыстырмалы талдау жүргізу. Мақалада сыбайлас жемқорлықты қабылдауды зерттеуде осы әдістерді қолданудың артықшылықтары мен кемшіліктері көрсетілген. Сыбайлас жемқорлықты қабылдауды зерттеуде қолдану үшін қарастырылатын әдістердің кейбірі оларға сыбайлас жемқорлық құрамдасы бойынша қосымша сұрақтарды енгізуді талап ететіні анықталды. Авторлар Ш.Шварц сауалнамасы мен Р.Янов-Булманның бейімделген сауалнамасы бойынша осындай сұрақтардың мазмұнын ұсынды. Зерттеу нәтижелері қарастырылған әдістердің әрқайсысын 1-ден 4-ке дейінгі шкаламен келесі критерийлер бойынша бағалауды білдіреді: сауалнама ауқымы, сауалнаманың күрделілігі, нәтижелерді талдау мен түсіндірудің күрделілігі, сыбайлас жемқорлықты қабылдау туралы сұрақтар интеграциясының күрделілігі.

түйін сөздер: құндылықтар, құндылық бағдарлары, сыбайлас жемқорлықты қабылдау, құндылық бағдарларды бағалау әдістемелері. 


\section{Introduction}

For a long time the only source of information about the corruption was criminal statistics. However, the comparative investigation of the corruption in countries or regions basing on the official statistics is impossible due to its incompleteness. In addition, the officially recorded corruption offences not always reflect the corruption degree in the society. Therefore, in recent years, the authoritative international organizations and scientists are interested in empiric investigations of corruption phenomena.

At present time, under the low effectiveness of fight against corruption in Kazakhstan, it is important to reveal the components stimulating the corruption, determine the axiological state of hidden social support of the corruption, study the reasons of the corruption institutionalization in the society. The solution of this problem can be implemented completely in the context of the social approach application to the corruption study.

The elimination of the corruption should be based on radical change of content of the whole assumption, life values at all levels. It is necessary to eliminate systematically the base on which the values are distorted, and change the ideological core of people through changing the social and economic, legal, and organizational factors and conditions through the education system, i.e. it is necessary to renew the content of their life values [1]. The legal, political, social and economic measures influence positively on the fundamental transformation of the life values.

In this context, it is important to study the propensity to corruption activities in the society and tolerance to corruption. To determine the propensity and tolerance to corruption, the authors propose to study the value-based orientations regulating a human behavior and influencing on definition of his goals and ways of its achievement.

\section{Methods of Research}

The research methodology is based on the comprehensive analysis and integrated systematization of the existing approaches to the study of the value-based orientations. The paper analyzes the Schwartz value survey, Rokeach value survey, the diagnostics of person value orientations structure by S.S. Bubnova, the world assumptions scale by R. Janoff-Bulman adapted by $\mathrm{O}$. Kravtsova. The research applied the methods of comparative, structural and criteria analysis.

\section{Sh. Schwartz Value Survey}

One of the main approaches of values study is a method of American psychologist Sh. Schwartz. This methodology analyzes the values on the level of common culture and on the personal level. Schwartz value survey consists of two parts. The first part of the survey investigates the values, ideals and beliefs influencing on a person. The second part of Schwartz survey is personal profile consisting of 40 person's characteristics that, in turn, describe the following 10 types of values:

1. Power. The functioning of social institutes requires status differentiation to some degree, and most of interpersonal relations in different cultures showed the combination of values of dominance/subordination. The main goal of this type of values is to achieve a social status or glory, control or domination over people and means (authority, wealth, social authority, saving of public image, public esteem). The values of Power and Accomplishments are focused on the social respect; however, the values of Accomplishment (for example, successful, ambitious) underline the active demonstration of the competence in a definite interaction, and the values of Power (authority, wealth) underline the achievement or saving of the dominant position inside the most common social system.

2. Achievement. The main goal of this type of values is personal success through the demonstration of the competence according to social standards.

The demonstration of the social competence (that makes the content of this value) under the conditions of domineering culture standards results in social approval. 
3. Hedonism. According to Sh. Schwartz survey the main goal of this type is determined as enjoyment or material pleasures (comfort, life of pleasure).

4. Stimulation. This is a derivative from organic need in diverse and deep emotions to support proper level of energy. The biologically grounded variations of stimulation need stipulated by the social experience can lead to individual different perception of this value importance. The motivational goal of these values is in novelty, deep emotions.

5. Self-reliance. The determining goal of this type of values is in independent thinking and selection of actions, creative and research activity. The self-reliance is a derivative from organic need in control and management, and from interaction needs in separateness and independence.

6. Universalism. The motivation goal of this type of values is understanding, tolerance, defense of well-being of all people and nature. The motivation goals of Universalism value can be derivatives from that needs of survival of groups and individuals that become clear when people come in touch with someone outside his medium or broaden the initial group.

7. Generosity. This is narrower defined "prosocial" type of values comparing to Universalism. The loyalty is focused on wellbeing in close daily interaction. This type is considered as derivative from need in positive interaction, need in affilitation and ensure of a group flourishing. The motivation goal of this type is saving of people wellbeing with which an individual is in often personal contact (usefulness, loyalty, condescension, honesty, responsibility, friendship, mature love).

8. Traditions. Any groups develop their own symbols and rituals the activity of which is determined by a group experience and fixed as traditions and customs. A traditional way of behavior becomes a symbol of group solidarity, expression of united values and a guarantee of survival. Traditions most often take the forms of religious rites, beliefs and behavior norms. The motivation goal is respect, acceptance and follow traditions and ideas existing in the culture (respect of traditions, humility, piety, acceptance of fate, moderateness).

9. Conformability. The determining motivation goal of this type is limitation, suppression, addictions and encouragements to actions that can harm others or do not correspond to social expectations. This is a derivative from a need to repel the addictions having negative social consequences (obedience, self-discipline, politeness, respect to parents and elderly people).

10. Safety. The motivation goal of this type is safety, harmony, stable society, relations, and a person; this is a derivative from the base individual and group needs. Sh. Schwartz assumes the existence of one common type of values for Safety, not two separate - group and individual level, as values related to groups express mainly the goal of safety for a person (social order, safety of a family, national safety, mutual agreement and help, purity, sense of belonging, health).

\section{Interpretation of results}

When analyzing and interpreting the results of Schwartz value survey it is important to note that two different types of values are considered:

1. Standard ideals, values of person of the level of creeds, and the structure of values having the largest influence on a person in whole, but not always expressed in real social behavior.

2. Values on the level of behavior, i.e. individual priorities, most often expressed in the social behavior of a person.

The difference of indicators by value types in these two parts of the survey, characterizing two levels of values functioning, reflect the value pressure that is accomplished, on one side, through the socialization, and on another side, through reference group and traditions.

Another important moment is that the number of issues included into each of 10 scales by Schwartz survey contains different number of questions. This means that points obtained by scales cannot be compared directly among each other. For the comparative analysis of different values, a testing per- 
son or a group should be normalized. This includes the following procedure:

A scale with the largest number of questions is found;

The largest point that could be reached by this scale is determined;

The indicators by all scales are divided onto this maximum point.

If the comparative analysis of indicators expressiveness by scales is not intended, and values expressiveness is supposed to be used within the correlation analysis, then it is possible to discard the indicators normalization by the scales of Schwartz value survey.

Advantages: additional questions can be easily included into the survey; the survey is widely specialized and allows for looking at broad range of interactions.

Disadvantages: the survey is big, probably needs payment or expect careless answers from respondents at some moment.

To analyze the corruption perception we suggest to add several statements to assess the second part (Table 1). The number of questions is the same as for other scales.

Table 1 - Additional questions for Schwartz survey to determine the level

of the corruption perception

\begin{tabular}{|l|l|l|l|l|l|l|}
\hline Questions & $\begin{array}{c}\text { Very } \\
\text { similar }\end{array}$ & Similar & $\begin{array}{c}\text { Similar to } \\
\text { some degree }\end{array}$ & $\begin{array}{c}\text { Similar a } \\
\text { little }\end{array}$ & $\begin{array}{c}\text { Not } \\
\text { similar }\end{array}$ & $\begin{array}{c}\text { Not simi- } \\
\text { lar at all }\end{array}$ \\
\hline $\begin{array}{l}\text { Supposes that the State } \\
\text { cannot protect him from } \\
\text { unfairness of its officials }\end{array}$ & & & & & & \\
\hline $\begin{array}{l}\text { In his telling, the States } \\
\text { work is not effective, it is } \\
\text { possible to use "lasers" in } \\
\text { law to improve own life }\end{array}$ & & & & & & \\
\hline $\begin{array}{l}\text { Assumes that a person } \\
\text { should use all possible } \\
\text { things even if these are } \\
\text { not legal }\end{array}$ & & & & & & \\
\hline $\begin{array}{l}\text { Is sure that most people } \\
\text { will take bribes if they } \\
\text { have an opportunity }\end{array}$ & & & & & & \\
\hline $\begin{array}{l}\text { Is sure that his position } \\
\text { can be used to help rela- } \\
\text { tives and friends }\end{array}$ & & & & & & \\
\hline
\end{tabular}

\section{Rokeach Value Survey}

Rokeach value survey allows investigating personal tendency and determining its relation to the surrounding medium, to other people, to himself, key motives of actions, the basis of "life philosophy".

- The nature of human values by Rokeach is as follows:

- Total number of values considered as human heritage is not large;

- All people have the same values, although to different degree;

- The values are arranged into the systems;

- The sources of human values are tracked in culture, society and its institutes, and a person;

- The influence of values is tracked in almost all social phenomena deserving study.

M. Rokeach differentiates two classes of values - terminal and instrumental:

The terminal values are defined by $M$. Rokeach as convictions that some terminal goal of individual existence (for example, happy family life, peace in the world) is worth to achieve it from personal and public points of view;

Instrumental values are convictions that some mode of actions (for example, hones- 
ty, rationalism) is, from personal and public points of view, preferable in any situations. In essence, the development of terminal and instrumental values generates quite traditional differentiation of values-goals and values-means.

Interpretation of results. The individual hierarchy of values obtained as the investigation result can be divided into three equal groups: 1-6);

- Preferred values, important (ranked

- Indifferent, insensible (7-12);

- Rejected, not important (ranked 13-18).

The ranks obtained for every of 36 values reflecting the importance of value for a tester, can be used in empirical investigations to reveal differences in groups or for the analysis of interactions of value-based orientations with other psychological phenomena.

The advantage of Rokeach survey application is quickness, easiness of procedure; the assumptions of the theory allows for good comparison of results among the countries. However, it is very difficult to integrate the corruption issues as the corruption itself is not a value. If to choose this method of investigation, then it is necessary to develop the second block that includes the questions on the corruption perception.

\section{The Diagnostics of Real Structure of Person Value-Based Orientations by S. Bubnova}

The diagnostics of real structure of person value-based orientations by S. Bubnova is designed to study the value-based orientations of a person in real conditions of life activities. The method is based on the assumption that the notions on important values are formed in the process of person socialization as a result of interiorization of universal cultural values.

S. Bubnova highlights three hierarchical levels in the system of value-based orientations of person corresponding to three levels of its study: 1) most general, abstract values: spiritual, social, material; 2) values became permanent in life and manifested as person's character: sociability, curiosity, activity, dominance etc.; 3) the most specific types of person's behavior as means to accomplish and settle the values-characters.

This method contains 66 closed questions aimed at study the way for actualization of value-based orientations of a person in real life conditions.

The advantage of the diagnostics of real structure of personal value-based orientations is the simplicity of data processing and its interpretation, easiness to include questions related to the corruption perception. The disadvantage is the longtime of survey that could affect the necessity in paid survey.

\section{The World Assumptions Scale by $R$. Janoff-Bulman Adapted by 0. Kravtsova}

The scale was developed under the cognitive concept of base assumptions of a person. According to it, one of the base feelings of a normal person is robust feeling of safety. The survey reveals such convictions as world loyalty, kindness of people, justice of world, ability to control the world, incident as a principle of the occurring events distribution, value of own "me", the degree of self-control (control over the occurring events), degree of luck or fortune.

Interpretation of results. The primary categories of convictions can be estimated as 3 generalized tendencies of relations: 1 . Common relation to loyalty of surrounding world is calculated as arithmetic mean between BW and BP (loyalty of world and kindness of people). 2. Common relation to sense of world, i.e. controllability and fairness of events is calculated as arithmetic mean between indicators of J (world's fairness), C (world controllability) and reverse $\mathrm{R}$ (incident). To obtain the indicator of reverse $R$, it is necessary to sum up the points reciprocal to $R$ regarding the middle of the scale. 3 . Conviction regarding own value, ability to manage the events and fortune is calculated as arithmetic mean between SW (value "me"), SC (self-control), and L (luck).

This survey allows for comparing the base 
convictions of different groups of people experienced different types of injury. According to the psychology the base convictions of a person are altered significantly under the influence of psychological trauma and traumatic events experienced by a person that result in complete deterioration of habitual life perceptions and behavior patterns.

The world assumptions scale can be also used for individual work: if the indicators by any scale of a person are too low, this should be considered while rendering the psychological support. The indicators by all scales should be above the middle, i.e. not less than 3.5 points to be considered as normal. The researchers suppose that more optimistic attitude to the world, surrounding people and a person itself favors larger psychological stability and success in daily life.

The advantage of the world assumptions scale is that it can be easily integrated with questions regarding the corruption perception, and interesting grouping of "values" will allow to make new conclusions on interconnection of the corruption perception and life approaches, easily collect and analyze data.

The disadvantage of this scale is very specific grouping and necessity to polish the scale so that the conclusions would be persuasive. Along with this it is possible to supplement the survey with the following several statements related to the corruption perception:

- I do not consider it bad to give money to an official to accelerate the thing that you can accomplish in the long-term;

- A lot of people would take bribes if they could;

- The State cannot protect its citizens against abuse of power of its officials;

- It is normal if a governmental official helps his relatives and friends with issues he can resolve even he breaks the law.

\section{Conclusion}

In general, the conducted analysis of the methods on study of the value-based orientations showed that all surveys, to this or that degree, will provide new information and allow to make definite conclusions. The criteria for the investigation method selection for us were the following: size of survey, complexity (fatigue of a respondent, and cost of survey), complexity of analysis and results interpretation, complexity of corruption perception questions integration. The results of the evaluation are shown in Table 2. The higher is the

Table 2 - Evaluation of methods on investigation of value-based orientations

\begin{tabular}{|c|c|c|c|c|}
\hline $\begin{array}{c}\text { Points (1 } \\
\text { - bad, } \\
- \text { good) }\end{array}$ & Size & Fatigue of respondent & Complexity of analysis & $\begin{array}{c}\text { Complexity of questions } \\
\text { integration }\end{array}$ \\
\hline 4 & $\begin{array}{c}\text { S. Schwartz value } \\
\text { survey }\end{array}$ & Rokeach value survey & Rokeach value survey & $\begin{array}{l}\text { Diagnostics of real structure } \\
\text { of person value-based ori- } \\
\text { entations by S. Bubnova }\end{array}$ \\
\hline 3 & Rokeach value survey & $\begin{array}{l}\text { The world assumptions } \\
\text { scale by R. Janoff-Bul- } \\
\text { man adapted by O. } \\
\text { Kravtsova }\end{array}$ & $\begin{array}{l}\text { Diagnostics of real } \\
\text { structure of person } \\
\text { value-based orientations } \\
\text { by S. Bubnova }\end{array}$ & S. Schwartz value survey \\
\hline 2 & $\begin{array}{c}\text { Diagnostics of real } \\
\text { structure of person } \\
\text { value-based orienta- } \\
\text { tions by S. Bubnova }\end{array}$ & $\begin{array}{c}\text { Diagnostics of real } \\
\text { structure of person val- } \\
\text { ue-based orientations } \\
\text { by S. Bubnova }\end{array}$ & $\begin{array}{l}\text { The world assumptions } \\
\text { scale by R. Janoff-Bul- } \\
\text { man adapted by O. } \\
\text { Kravtsova }\end{array}$ & $\begin{array}{l}\text { The world assumptions scale } \\
\text { by R. Janoff-Bulman adapt- } \\
\text { ed by O. Kravtsova }\end{array}$ \\
\hline 1 & $\begin{array}{l}\text { The world assump- } \\
\text { tions scale by R. } \\
\text { janoff-Bulman adapt- } \\
\text { ed by O. Kravtsova }\end{array}$ & $\begin{array}{c}\text { S. Schwartz value } \\
\text { survey }\end{array}$ & S. Schwartz value survey & Rokeach value survey \\
\hline
\end{tabular}


method point, the more preferable it is for the aims of this investigation.

The most preferable method to study the value-based orientations in the context of the corruption investigation, in our opinion, is S. Schwartz value survey. In future, it is supposed to supplement the second part of the survey with questions on determining the availability of propensity to break the rules for own benefit, and make a survey to reveal the level of the corruption perception in Kazakhstan society.

\section{References}

1 Komdrashov P.N. Social conditions, life values and its connection with corruption // Topical issues of scientific base of the state policy of Russian Federation in the field of anti-corruption fight.- 2019. - \# 1. - P. 257-278. doi: 10.17506/articles.anticorruption.2018.257278

2 Schwarts S.H., Sagiv L. Identifying Culture-Specifics in the Content and Structure of
Values // Journal of Cross-Cultural Psychology. - 1995. - \# 26(1). - P. 92-116

3 Schwartz, S. H. Toward a universal psychological structure of human values [Text] $/ \mathrm{S}$. $\mathrm{H}$. Schwartz, W. Bilsky // Journal of personality and social psychology. - 1987 - № 5. - P. 550-562.

4 Karandashev V.N. Schwartz value survey to study person values: concept and methodical guide. - St. Petersburg.: Rech, $2004-70$ p.

5 Rokeach, M. Believes, attitudes and values [Text] / M. Rokeach. - San Francisco : Jossey-Bac Co., 1972. - 214 p.

6 Geger A.E., Geger S.A. Study of value orientations: specifics of different approaches // Bulletin of Tomsk State University. - 2015. - \# 399. - P. 13-17. DOI: 10.17223/15617793/399/3

7 Bubnova S.S. Method of diagnostics of individual structure of person value-based orientations // Methods of psychological diagnostics. - 1994. - Issue 2. - P. 144-157.

8 Bubnova S.S. Methods of diagnostics of person value-based orientations. - M., 1995. $-49 \mathrm{p}$.

9. Janoff-Bulman R. World assumptions scale [Text] / R. Janoff-Bulman / Psychodiagnostics of person tolerance / Edited by G.U. Soldatova, L.A. Shaygerova. M.: "Smysl" Publ. - 2008. - 172 p.

\section{INFORMATION ABOUT AUTHORS}

Satybaldin Azimkhan

Rezer Tatyana

Panzabekova Aksana

Сатыбалдин Әзімхан Әбілқайырұлы

Резер Татьяна

Михайловна

Панзабекова Аксана Жакитжановна

Сатыбалдин Азимхан Абилкаирович

Резер Татьяна

Михайловна

Панзабекова Аксана Жакитжановна
Doctor of Economic Sciences, professor, academician RAS RK, Institute of Economics SC MES RK, Almaty, Kazakhstan, e-mail: ieconomkz@gmail. com ORCID: https://orcid.org/0000-0001-7421-4472

Doctor of Pedagogics, Professor of the Department of Theory, Methodology and Legal support of the State and Menicipal administration of UrFU named after B.N. Yeltsin, ORCID: https://orcid.org/0000-00024793-9918 e-mail: tmrezer@mail.ru

Candidate of Economic Sciences, Associate Professor, Chief Researcher, Institute of Economics SC MES RK, ORCID: https://orcid.org/0000-00026389-9637, e-mail: aksanat@mail.ru, Almaty, Kazakhstan

экономика ғылымдарының докторы, профессор, ҚР ҰҒА академигі, ҚР БҒМ ҒК Экономика институты, Алматы, Қазақстан, e-mail: ieconomkz@gmail.com ORCID: https://orcid.org/0000-0001-7421-4472

Пеагигика ғылымдарының докторы, Б.Н. Ельцин атындағы ОрФу мемлекеттік және муниципалдық басқару теориясы, әдіснамасы және құқықтық қамтамасыз ету кафедрасының профессоры, ORCID: https://orcid.org/0000-0002-4793-9918, Екатеринбург, Ресей,

экономика ғылымдарының кандидаты, доцент, бас ғылыми қызметкер, ҚР БҒМ ҒК Экономика институты, Алматы, Қазақстан, e-mail: aksanat@mail.ru ORCID: https://orcid.org/0000-0002-6389-9637

Доктор экономических наук, профессор, академик НАН РК, директор Института экономики КН МОН РК, Алматы, Казахстан, e-mail: aksanat@mail.ru ORCID: https://orcid.org/0000-0001-7421-4472

Доктор педагогических наук, профессор, УрфУ имени Б.Н. Ельцина, ORCID: https://orcid.org/0000-0002-4793-9918, Екатеринбург, Россия, e-mail: tmrezer@mail.ru

К.э.н., доцент, главный научный сотрудник, Институт экономики KH MOH PK, ORCID: https://orcid.org/0000-0002-6389-9637. Алматы, Казахстан, e-mail: aksanat@mail.ru 